\title{
On the Construction of Network Discourse System of Ideological and Political Education in Colleges and Universities under the Background of "Micro-era"
}

\author{
MingKun Jiang ${ }^{1, \text { a }}$ \\ ${ }^{1}$ Heilongjiang University of Technology, Heilongjiang, Jixi ,158100 \\ jmkhlj@163.com
}

\begin{abstract}
Keywords: Ideological and political education in colleges and universities; Micro-era; Internet discourse; Construction
\end{abstract}

\begin{abstract}
In the context of micro-era, the discourse right of ideological and political education in colleges and universities is a mode of discourse communication. It has certain characteristics of the times, and it is based on Internet technology to realize the discourse power. In the context of micro-era, the scope of discourse power of ideological education in universities has been broadened, and previous forms of discourse carriers and information dissemination have been changed. This has promoted the diversification of the form and content of ideological education in universities. But at the same time, it also brings certain challenges to the ideological education work in universities. It needs high corrections to view the advantages and disadvantages of micro media, and then make full use of micro media to improve the effectiveness of ideological education. This article firstly analyzes the characteristics of the micro-era, and then puts forward the path to construct the discourse right of the ideological and political education in universities: the diversification of ideological education content, the democratization of educational concepts, the "miniaturization" of ideological education system management, and the establishment of ideological education discourse right operation mechanism.
\end{abstract}

\section{Introduction}

"In an ideological and cultural position, if Marxism and the proletariat didn't occupy it. Various non-Marxist and non-proletarian ideas and even anti-Marxist ideas will occupy it." Especially in the context of the continuous development of the Internet and the increase in the number of users in the network, the right to effectively occupy the network of ideological and cultural positions and ensure the right to speak of the network culture position is not only related to the healthy growth of the young generation, but also to the leadership of the Internet culture. And the harmony and stability of the entire society are of great significance. Therefore, strengthening the construction of online discourse rights in ideological and political education in colleges is not only related to the innovation of ideological and political education in colleges and universities, but also an inevitable requirement for strengthening the propaganda and ideological work in colleges and universities in the new situation. It is also the realization of cyber culture leading and occupying the network ideological highlands. In view of this, this article analyzes the status quo of online ideological and political education discourse in universities in the context of "micro-era" and combines with the generation mechanism of discourse rights in ideological and political education in colleges and universities, analyzes the characteristics of ideological and political education online discourse right. Finally, it explores the strategies for constructing the discourse power of ideological and political education in colleges and universities.

\section{The Connotation of "micro era"}

In the context of the rise of new media, the strong demand for rapid and convenient human communication is the catalyst and booster for the birth and continuous development of Weibo. However, the widespread application and popularization of Weibo promoted the arrival of "micro-era". Weibo opened the prelude to the "micro-era". Wechat, micro-public welfare, 
micro-novel and micro-movie emerged and began to influence and change the way of thinking of college students and life patterns. Weibo, WeChat and other self-media will mark the beginning of the "micro-era."

With the rise of Weibo, there are many definitions of "micro-era." For example, Baidu Encyclopedia defines the "micro-era": the instantiation of micro-blog as the representative of the media, and the short refining as the characteristic of cultural communication. However, the "micro-era" is not a single concept. It is a macro-level summary and an established stage of cultural development. "Micro-era" is not a single concept of existence, and it has different connotations from different perspectives.

From the "micro-era" content. In recent years, all kinds of information dissemination methods and application tools with the word "micro" have swept across the country, and the "micro" wind has spread over time. Represented by WeChat and Weibo, micro-films, micro-films, micro-power, micro-public welfare, micro-travel, micro-fashion and other micro-products lead micro-times and permeate into the daily life of the public.

Weibo is a typical production of "micro-era", and it is a new thing that is representative and influential. Since launching in July 2009, registered users have exceeded 400 million, and users have issued more than 100 million microblogs per day. The popularity of Weibo followed by a large number of micro-media applications have become daily hot. Micro-novel that as a typical application derived from microblogging, it not only has a concise language, a short and concise language, and a definite ending. It can also interact with readers at any time. The micro-story of no more than 140 words makes the reader memorable. Micro-film is another bright point after the microscopic theory. Its "minority" lies in micro-production, micro-time, and micro-investment, and it has become popular in the form of short, flexible, and concise forms. Micro-film will focus more attention on the details and posture of traditional films in terms of small details, small people or "miraculous" and fictional "suspense". At the same time, because of its closeness to life, microfilms do not require high equipment and actors, which also helps many ordinary people get more attention through microfilms. At the same time, there are also short-acting and convenient micro-public charities that make use of personal love, a micro-travel that can be said to go and lead, and lead the fashion and create the micro fashion of the people. A variety of micro-media have become popular in the network, and WeChat currently dominates the branch. In the circle of friends, it is easy to understand the world and even to be a micro-branch in leisure time. A simple APP is like a person's whole life. This confirms that the "micro-era" is a time of great change and rich content.

\section{The Present Situation of Ideological and Political Education in Colleges and Universities in the Background of "Micro-era"}

The "micro-era" has changed people's traditional ways of information exchange, interpersonal communication, cultural expressions, and social actions. This has changed the public opinion environment, cultural environment, and social psychological environment of ideological and political work. It has challenged the ideological and political work in the new period. As the new darling of online media, Weibo is like a double-edged sword. Its strong penetration and attractiveness as well as its extensive and far-reaching influence on college students make the ideological and political education work in colleges and universities face new difficulties and opportunities. The dissemination of information in the "micro-era" is characterized by diversity, cracking, and intractability. Lacking of proper guidance and control will affect the university students' world outlook, outlook on life, and values. Moreover, the traditional ideological and political work methods and efficiency are difficult to keep pace with the times. Ideological and political education is often rigidly adhered to traditional hard indoctrination methods. There are also some obstacles in the interaction and interaction with college students, making it difficult for ideological and political education to adapt to the requirements of the new era and fail to achieve the desired results. The main problems are as follows.

Traditional Ideological and Political Education Methods have Limitations. For a long time, the ideological and political education in colleges and universities has mostly been confined to 
schools and classrooms, using traditional indoctrination forms, classroom education methods, typical case laws, and infection incentive methods. These methods have one thing in common: the initiative of education is in the hands of teachers, and it has certain controllability. Because of the non-barrier and timeliness of information disseminated by Weibo, college students can more easily and freely publish and receive any information, easily accept negative or negative information, affect one's outlook on life and values, and influence the positive effect of ideological and political work. The ideological and political work has lost control over the information of college students. The speed and quantity of information obtained by college students through Weibo far exceeds the range that educators can control. This makes the traditional education methods not keep up with the changes of the times. The positive effect of college students' ideological and political education has been greatly impacted.

At present, although many college and university departments have proposed online ideological education media to meet the needs of college students in order to cope with the advent of the Internet age, due to the lack of formal innovation and the lack of initiative and interactivity in online education, it is impossible to satisfy contemporary college students for new media and concepts. The needs of the government will not be able to meet the needs of the ideological and political education innovation in the new era. If we can't make better use of the platform of the "micro-era" new media, ideological and political educators will have difficulty understanding the trends of university students' thinking and will not be able to carry out effective ideological and political education for them.

The Content of Traditional Ideological and Political Education has Narrowness. The content of traditional ideological and political education is mainly idealism, patriotism and moral education. Socialist ideology guided by Marxism is at the core, and the network should have assumed the mission of promoting the core idea of socialism. However, due to the rapid development of the Internet, it has long been the methods of network supervision are backward and insufficient, and the content that college students encounter on the Internet is uneven. The appearance of "Weibo" has gradually made the dissemination of information gradually detached from the mainstream ideology of society and school ideological and political education, and has even caused a huge impact on the mainstream values of the society. College students' attitudes towards life and values have been unprecedentedly hit and impacted. In order to avoid the negative impact on the effect of ideological and political education, the contents of ideological and political education in universities urgently need to be enriched and innovated.

Traditional Ideological and Political Educators Work Lagging Behind. In the traditional ideological and political education process, educators are in an active position to control information. The appearance of Weibo has enabled college students to receive a large amount of new information at any time and place. The active status of ideological and political educators has been weakened to a great extent. At the same time, undergraduates have also shaken the professional quality and authority of ideological workers. It will facilitate the advancement of ideological education. If ideological and political educators fail to grasp and guide information in a timely manner, it will be difficult to master the ideological dynamics of university students and influence the active guiding role of ideological education. Therefore, traditional ideological and political educators urgently need to innovate their working methods and improve their work quality.

\section{Construction of Network Discourse System of Ideological and Political Education in Colleges and Universities}

Diversification of Ideological and Political Education and Democratization of Educational Concepts. Micro-media mainly includes Weibo, Wechat, etc. Micro-media is one of the platforms for information exchange and ideological education in universities. It is the main way to change the traditional single-teaching model. At the same time, it is also a key factor to improve the timeliness and pertinence of ideological and political education in colleges and universities. At this stage, as micro-media goes deep into all aspects of life, while undergraduates accept the influence of various information from the outside world, their ideological concepts have also changed and become more 
diversified, which has brought certain challenges for the ideological education work. To this end, colleges and universities should keep abreast of the development trend of the micro-era, combined with their own actual situation, use Internet technology and platform to broaden the ideological and political education channels, change the mode of knowledge dissemination, and adopt a proactive approach to meet the challenges posed by micro-media. In addition, ideological and political educators in colleges and universities should promptly examine the college students' behavioral status and cognitive attitudes towards micro-media exposure, and analyze the depth and breadth of the influence of micro-media on college students, and then make full use of the advantages of micro-media to promote micro-media thinking to be the effective carrier of political education. Under the micro-era background, the content of ideological education in universities should be diversified and the educational concept should be democratized. This not only includes ideological education and ideological guidance for students, but also includes humanistic education and psychological counseling education. This will not only increase the discourse height of the ideological and political education network in universities, but also increase the intensity of the discourse implementation of ideological and political education. And to create professional colleges and universities ideological education brand, expand the implementation of ideological and political education, providing the public foundation for the construction of network discourse system of ideological education.

Ideological education system management "miniaturization". The development of micro-media has a far-reaching impact on the society. At the same time, it has also formed the development trend of Weibo and Wechat. The attention of college students has shifted to the micro-media, and has become one of the main channels of ideological and political education in universities. In the micro era, the precondition for improving the discourse system of ideological and political education in universities is to promote the miniaturization of ideological education management. In the management of ideological education, the method of disseminating micro-era knowledge was introduced into it, and the combination of ideological guidance and professional teaching of two kinds of knowledge dissemination methods, which in turn impelled students to deepen their understanding of the ideological education management system, and to achieve " obey". This can not only improve the implementation of ideological and political education, but also improve the discourse of ideological and political education, and thus lay a solid foundation for the construction of the political education network discourse system.

Establishing Ideological and Political Education Network Discourse Operation Mechanism. The official Weibo on college campuses is an effective channel for the dissemination of ideological and political education in colleges and universities. Constructing and improving the discourse system of ideological and political education can play the role of official microblogs in colleges and universities and lay a solid foundation for the construction of ideological cyberdiscourse. First of all, in order to promote the sound development of Weibo's operation mechanism and construct the discourse system of the political education network, schools should plan Weibo events on a regular basis and be responsible for the construction of network discourse and the development of Weibo operation plans. Secondly, improve the assessment system. Its purpose is to improve the discourse of ideological and political education in colleges and universities, and to improve Weibo operations. Finally, improve the training mechanism, and lay a solid foundation for the construction of ideological and political education online discourse.

\section{Summary}

Under the micro-era background, in the process of constructing online discourse rights of college ideological and political education, we must focus on the core values of socialism, pay attention to the promotion and education of socialist core values at the network level, and cultivate a sense of common belonging to the socialist core values of college students, making the socialist core values become the conscious pursuit of college students, becoming a common spiritual culture in which college students connect with each other, forming the common belief in nurturing and practicing socialist core values. Universities should make full use of the advantages of micro-media, and give 
play to their scientific guiding role, formulate targeted and scientific teaching programs and teaching goals, and guide college students to establish scientific and correct values. In addition, ideological and political educators in universities should strengthen their learning, improve their overall quality, promote the overall development of college students, and lay a solid foundation for the establishment of ideological and political education in universities.

\section{References}

[1] Ensink K, Normandin L, Target M, et al. An Inquiry into Students' Ideological and Political Education in the Construction of Campus Culture with Nautical Characteristics[J]. Science Education Article Collects, 2012, 134(1-2):133-44.

[2] Jiang D X. Reflections on the comprehensive functions of ideological and political education on BBS in colleges and universities[J]. Journal of Dalian University of Technology, 2007.

[3] Yan L. The Youth Volunteer Activities and the Effectiveness of Ideological and Political Education in University[J]. Journal of Chengdu University, 2009.

[4] Yan L I, Zeng W L, Hai-Tao H E. An Analysis of the College Students' Ideological and Political Education Vector under the New Media Environment[J]. Journal of Chongqing University of Posts \& Telecommunications, 2010.

[5] Ling X P, Deng B J. A Study on Ideological and Political Education in University in the Era of Big Data[J]. Journal of Guangxi Normal University, 2015.

[6] Wang-Sheng, Wang J F. Research on the Innovation of Ideological and Political Education of University Students in the We-Media and Big Data Era[C]// International Conference on Measuring Technology and Mechatronics Automation. IEEE, 2017:403-407.

[7] Wang Y. Big Data Era Influence on College Students' Ideological and Political Education and Innovation Strategy[C]// Eighth International Conference on Measuring Technology and Mechatronics Automation. IEEE, 2016:126-128.

[8] Zhu F, Feng Y. A Research on Ideological and Political Education Innovation in Grass-roots Unit of the Public Security Border Forces under Big Data Conditions[J]. Journal of Chinese Peoples Armed Police Force Academy, 2016.

[9] Zeng Q J. Research on the Innovation of Ideological and Political Education of University Students in the Big Data Era[J]. Theory \& Practice of Education, 2015.

[10] Chen D. Soviet Area Red Culture Explore Some Values in Local Ideological and Political Education:Take Sanming Soviet Area Red Culture as an Example[J]. Journal of Chengdu University of Technology, 2017.

[11] Tao Z M, University L N. Research on the ideological and political education in colleges and universities from the perspective of people oriented[J]. Journal of Jiamusi Vocational Institute, 2017.

[12] $\mathrm{Xu} \mathrm{J}$, University $\mathrm{J} \mathrm{M}$. Improve the Evaluation Mechanism of Political and Ideological Counselor Enhance the Ideological and Political Education Effectiveness of University Student[J]. Management Observer, 2017.

[13] Ding F. Analysis of the Ideological and Political Education of College Students under the Background of Internet Plus[J]. Theory Research, 2017.

[14] Fan, Linjie. "Research on Individualized Service of Ideological and Political Education in Universities in Big Data Era." Journal of Changchun University (2017). 